\title{
Antibacterial Activity of Some Molecules Added to Rabbit Semen Extender as Alternative to Antibiotics
}

\author{
María Pilar Viudes-de-Castro ${ }^{1, *}$, Francisco Marco-Jimenez ${ }^{2} \mathbb{D}$, José S. Vicente ${ }^{2} \mathbb{D}$ and Clara Marin ${ }^{3} \mathbb{D}$ \\ 1 Centro de Investigación y Tecnología Animal, Instituto Valenciano de Investigaciones Agrarias (CITA-IVIA), \\ Polígono La Esperanza n 100, 12400 Segorbe, Spain \\ 2 Instituto de Ciencia y Tecnología Animal, Universitat Politècnica de València, 46022 Valencia, Spain; \\ fmarco@dca.upv.es (F.M.-J.); jvicent@dca.upv.es (J.S.V.) \\ 3 Departamento de Producción y Sanidad Animal, Salud Pública Veterinaria y Ciencia y Tecnología de los \\ Alimentos, Instituto de Ciencias Biomédicas, Facultad de Veterinaria, Universidad Cardenal Herrera-CEU, \\ CEU Universities, Avenida Seminario s/n, 46113 Moncada, Spain; clara.marin@uchceu.es \\ * Correspondence: viudes_mar@gva.es
}

check for updates

Citation: Viudes-de-Castro, M.P.; Marco-Jimenez, F.; Vicente, J.S.; Marin, C. Antibacterial Activity of Some Molecules Added to Rabbit Semen Extender as Alternative to Antibiotics. Animals 2021, 11, 1178. https://doi.org/10.3390/ani11041178

\section{Academic Editors: Rosa}

María García-García and Maria

Arias Alvarez

Received: 21 March 2021

Accepted: 17 April 2021

Published: 20 April 2021

Publisher's Note: MDPI stays neutral with regard to jurisdictional claims in published maps and institutional affiliations.

Copyright: (c) 2021 by the authors. Licensee MDPI, Basel, Switzerland. This article is an open access article distributed under the terms and conditions of the Creative Commons Attribution (CC BY) license (https:// creativecommons.org/licenses/by/ $4.0 /)$.
Simple Summary: This study was conducted to evaluate the antibacterial activity of two aminopeptidase inhibitors and chitosan-based nanoparticles in liquid-stored rabbit semen. This study reports that the aminopeptidase inhibitors used to prevent bacterial growth could be used in semen extender as a suitable alternative to antibiotics.

Abstract: Although great attention is paid to hygiene during semen collection and processing, bacteria are commonly found in the semen of healthy fertile males of different species. As the storage of extended semen might facilitate bacterial growth, extenders are commonly supplemented with antibiotics. This study aimed to evaluate the antibacterial activity of ethylenediaminetetraacetic acid (EDTA), bestatin and chitosan-based nanoparticles added to rabbit semen extender and their effect on reproductive performance under field conditions. Four different extenders were tested, supplemented with antibiotics (TCG+AB), with EDTA and bestatin (EB), with EDTA, bestatin and chitosan-based nanoparticles (QEB) or without antibiotics (TCG-AB). Extended semen was cooled at $15{ }^{\circ} \mathrm{C}$ for three days. Cooled samples were examined for bacterial growth and semen quality every $24 \mathrm{~h}$ for 3 days. The enterobacteria count increased considerably during storage at $72 \mathrm{~h}$ in semen extended with TCG+AB and TCG-AB, while extenders EB and QEB showed a bacteriostatic effect over time. After 24, 48 and 72 h, quality characteristics were retained in all groups, with no significant motility differences, either in acrosome integrity, membrane functionality or the viability of spermatozoa. Additionally, bacterial concentration present in fresh semen did not affect reproductive performance. In conclusion, EDTA and bestatin exerted a potent bacteriostatic effect over time and could be used as an alternative to conventional antibiotics in rabbit semen extenders.

Keywords: artificial insemination; antibiotics; antibacterial activity; semen quality; reproductive performance

\section{Introduction}

Artificial insemination (AI) is a highly efficient assisted reproductive technology used worldwide in animal breeding. Semen from healthy fertile males from different species contains bacteria stemming from natural colonisation in the male tract and the environment, despite the application of strict hygienic measures during collection and manipulation processes [1], so international directives stipulate the addition of antibiotics to semen extenders to prevent bacterial growth. However, as a consequence of excessive antibiotics use in different fields such as human medicine, veterinary medicine, livestock and fish production, agriculture and food technology, microbial resistance has emerged as one of the main concerns worldwide $[2,3]$. 
Semen contaminated with bacteria such as Enterobacteriaceae might adversely affect the quality of semen used for AI [4], in addition it is an important hygiene indicator [5-8]. Even though most of them are non-pathogenic bacteria, they can negatively influence sperm quality and longevity if present in high concentrations $[6,7,9,10]$. Additionally, several studies have shown that the seminal plasma of different species contains aminopeptidases [11-16]. Aminopeptidase activity promotes the proliferation of many bacteria that act as virulence factors, essential for the survival and maintenance of many microbial pathogens $[17,18]$.

Nowadays, bacterial resistance to commonly used antibiotics and the global spread of resistance genes has become a serious health problem. Bacteria could counteract the actions of antimicrobials through different mechanisms, such as enzyme modification, alteration of the target binding sites, active efflux pumps or decreased permeability of bacterial membrane [19]. This resistance may occur through spontaneous mutations or by the horizontal transfer of mobile genetic elements from other bacteria, phages and/or the transmission of resistance genes from the environment $[19,20]$. In this sense, the transmission of resistance genes plays an important role in the spread of antimicrobial resistance among strains $[19,20]$ and efforts need to be made to replace conventional antibiotics in the animal production industry. Some alternatives to conventional antibiotics in semen extender, such as colloid centrifugation [21-24] or removal of seminal plasma [25], have been investigated in different species. However, these techniques involve an increase in the processing time of semen. Others approaches for overcoming bacterial growth include the use of active molecules such as EDTA, [26], chitosan [27,28], nanoparticles [29], peptides [30,31] and aminopeptidase inhibitors [18,32], etc., with recognised antibacterial activity. EDTA is known to increase the outer cell wall permeability of Gram-negative bacteria, allowing other molecules easier access into the cell, facilitating an alteration or inhibition of its metabolism [33-35]. Chitosan, a biocompatible biodegradable and non-toxic polycationic copolymer extensively used as material for encapsulation and controlled release of chemicals [36], interacts with the bacterial cell membrane and causes cell lysis [37,38]. Furthermore, the encapsulation of GnRH in chitosan-based nanoparticles added to the extender supplemented with EDTA and bestatin can overcome the poor stability of the GnRH analogues in the presence of aminopeptidases [16,39] and allows to reduce the hormonal concentration used without affecting the reproductive performance of female rabbits [40]. This method of inducing ovulation in rabbit AI was developed to increase the welfare of rabbit insemination procedures and reduce the concentration of GnRH analogues added to semen extenders.

Against this background, this study aimed to evaluate the antibacterial activity of EDTA, bestatin and chitosan-based nanoparticles added to rabbit semen extender and their effect on the reproductive performance under field conditions, with a view to improving the sustainability of the rabbit production system.

\section{Materials and Methods}

The chemicals used in this study were purchased from Sigma-Aldrich (Merck Life Science S.L.U. Madrid, Spain). Animal housing and the protocols for semen collection and AI were approved by the Animal Care and Use Committee of Centro de Tecnología Animal, Instituto Valenciano de Investigaciones Agrarias. All animals were handled according to the European regulations for the care and use of animals for scientific purposes (European Commission Directive 2010/63/European Union).

\subsection{Extenders Composition}

Four different extenders were tested (Table 1). The solution used as a carrier for the molecules tested was Tris-citric acid-glucose (TCG extender; [41]). Chitosan and alginate were dissolved $(0.05 \%)$ in the TCG supplemented with EDTA $(20 \mathrm{mM})$ and bestatin $(10 \mathrm{mM})$ according to Casares-Crespo et al. [40]. The nanoparticles were formed spontaneously in the coacervation process, directly after mixing the solutions of chitosan and alginate (4:1) through magnetic stirring ( 600 rpm) for $30 \mathrm{~min}$ at room temperature. 
Table 1. Semen extenders composition.

\begin{tabular}{cc}
\hline Group & Composition \\
\hline TCG + AB & TCG extender supplemented with $100 \mathrm{IU} / \mathrm{mL}$ penicillin $+100 \mu \mathrm{g} / \mathrm{mL}$ streptomycin \\
\hline EB & TCG supplemented with EDTA $(20 \mathrm{mM})$ and bestatin $(10 \mathrm{mM})$ \\
\hline QEB & TCG supplemented with EDTA $(20 \mathrm{mM})$, bestatin $(10 \mathrm{mM})$ and nanoparticles of \\
chitosan-alginate $(0.05 \%)$
\end{tabular}

\subsection{Experimental Design}

2.2.1. Experiment 1: In Vitro Evaluation

Animals

Twelve males of New Zealand White origin were kept individually under similar conditions to those described by Viudes de Castro et al. [16].

\section{Semen Collection}

Semen from males was collected twice a week in three replicates. Strict attention was paid to the hygiene of collection equipment and semen samples were collected into sterile tubes. Semen collection and evaluation were conducted in accordance with Casares Crespo et al. [39]. Finally, all the ejaculates were pooled.

The pool was split into four equal fractions and diluted with the appropriate extender (dilution 1:10; $v: v$ ). The pools used in the experiment presented an average sperm concentration of 385 spermatozoa mL-1. Diluted samples were cooled at $15^{\circ} \mathrm{C}$ for three days. Cooled samples were examined for bacterial growth, total motility, percentage of live sperm and membrane status every $24 \mathrm{~h}$ for 3 days.

\section{Microbiological Analysis}

Using Enterobacteriaceae as the sentinel, bacterial growth was evaluated by enumeration. Tenfold dilution series were performed in each extender to $10^{-6}$, and $1000 \mu \mathrm{L}$ of each dilution was then plated onto Violet Red Bile Dextrose Agar (VRBD agar, Scharlab ${ }^{\circledR}$, Barcelona, Spain) per duplicate; after homogenisation of the plate, $10 \mathrm{~mL}$ of VRBD were added to seal the plate. Plates were incubated for $24-48 \mathrm{~h}$ at $37 \pm 1^{\circ} \mathrm{C}$. Typical colonies were counted, and the least dilute pair of plates that contained an average of between 30 and 150 colonies was used to calculate the number of bacteria $(\mathrm{CFU} / \mathrm{mL})$.

\section{Seminal Quality Evaluation}

Percentage of total motile sperm was evaluated using a computer-assisted sperm analysis system (ISAS Proiser, Valencia, Spain) as described by Viudes-de-Castro et al. [13]. Briefly, ten microlitres of each sample was placed into a $10 \mathrm{~mm}$ deep Makler counting chamber (Sefi Medical Instruments, Haifa, Israel). Sperm motility was assessed at $37^{\circ} \mathrm{C}$ by negative phase contrast objective at a magnification of X100 (NIKON E-400 microscope, Izasa Scientific, Barcelona, Spain). Six microscopic fields were captured for each sample. A minimum of 400 sperm were evaluated using the same criteria described by Casares Crespo et al. [39].

Flow cytometric analyses to assess viability (integrity of sperm membrane) and acrosome integrity were performed with a CytoFLEX Flow Cytometer (Beckman Coulter, S.L.U., Barcelona, Spain) equipped with red $(638 \mathrm{~nm})$, blue $(488 \mathrm{~nm})$ and violet $(405 \mathrm{~nm})$ lasers and operated by the CytExpert Software v.2.3 (Beckman Coulter, S.L.U., Barcelona, Spain). The cytometer was calibrated daily using specific calibration beads provided by the manufacturer. Data were collected from 10,000 events. Gating the spermatozoa population after Hoechst 33,342 staining eliminated non-sperm events. Doublets and clumps were further excluded by using a plot of side scatter area and side scatter height followed by a gate of simple events. A compensation overlap was performed before each experiment. A 
FITC-PNA/PI/Hoechst triple staining method, validated for rabbit semen in our laboratory, was used to determine viability and acrosomal status. To this end, $100 \mu \mathrm{L}$ of semen at $30 \times 10^{6}$ sperm $/ \mathrm{mL}$ were stained with $0.5 \mu \mathrm{L}$ Hoechst $33,342(0.5 \mathrm{mg} / \mathrm{mL})$ for $20 \mathrm{~min}$ at $37^{\circ} \mathrm{C}$ without light. Subsequently, $1.5 \mu \mathrm{L}$ FITC-PNA $(1 \mathrm{mg} / \mathrm{mL})$ and $0.5 \mu \mathrm{L} \mathrm{PI}(1 \mathrm{mg} / \mathrm{mL})$ were added to the sample and incubated $10 \mathrm{~min}$ at $37^{\circ} \mathrm{C}$ without light. Then $400 \mu \mathrm{L}$ of TCG extender [36] were added to obtain a final concentration of $6 \times 10^{6}$ sperm $/ \mathrm{mL}$. PI-negative sperm were considered viable. The normal apical ridge (NAR) percentage was calculated as the proportion of acrosome intact sperm.

Membrane functionality analysis was assessed by hypo-osmotic swelling test (HOST). An aliquot of $100 \mu \mathrm{L}$ of diluted semen was added to $1 \mathrm{~mL}$ of warmed $150 \mathrm{mOsm}$ hypoosmotic swelling solution containing sodium citrate $(25 \mathrm{mmol} / \mathrm{L})$ and fructose $(75 \mathrm{mmol} / \mathrm{L})$ and incubated for $30 \mathrm{~min}$ at $37^{\circ} \mathrm{C}$. Subsequently, $10 \mu \mathrm{L}$ of each sample were placed on a clean glass slide with a coverslip, and sperm swelling was assessed under phase-contrast microscopy. For each sample, a total of 200 spermatozoa were examined.

\subsubsection{Experiment 2: In Vivo Evaluation}

Eight hundred and ninety-seven crossbreed females from a commercial farm (Altura, Castellón, Spain) were inseminated using fresh semen from 50 adult males belonging to a paternal rabbit line (Line $\mathrm{R},[42]$ ). Animal housing and seminal evaluation were similar to the previous experiment. All the ejaculates were pooled. The pool was split into four aliquots and diluted 1:10 with the four experimental extenders. After diluting the semen in the four experimental extenders, the insemination was initiated immediately. Each female was randomly assigned to one of the four experimental groups and was inseminated with $0.5 \mathrm{~mL}$ of semen using standard curved cannulas $(24 \mathrm{~cm})$. About $2 \mathrm{~h}$ elapsed between the first and the last inseminated female. At birth, pregnancy rate (number of kindlings/number of inseminated does) and prolificacy (total number of kits born) were evaluated.

\subsection{Statistical Analysis}

To analyse the effect of extender on Enterobacteriaceae growth, motility, viability, acrosome integrity and membrane functionality, a general linear model was used. The extender, refrigeration time and their interaction were taken as fixed effects and, in the case of seminal parameters, the corresponding parameter of the pool was introduced as a covariate in the analysis. A chi-square test was used to test differences in pregnancy rate at birth between groups. For the total number of kits born per litter, an ANOVA was performed, including as fixed effect the extender group and pool as covariate. All analyses were performed with the SPSS 26.0 software package (SPSS Inc., Chicago, IL, USA). Values were considered statistically different at $p<0.05$.

\section{Results}

\subsection{Experiment 1: In Vitro Evaluation}

Results for bacterial growth are shown in Figure 1. The enterobacteria count increased considerably during storage at $72 \mathrm{~h}$ (Figure 1) in TCG+AB and TCG-AB groups. At $24 \mathrm{~h}$, a significant increase of bacterial growth was observed in semen extended in TCG-AB (extender without antibiotics) compared to the rest of the groups. Additionally, at this time point, a significant decrease in bacterial growth was observed in the EB group versus the TCG $+\mathrm{AB}$ (extender with antibiotics) or QEB groups. At $48 \mathrm{~h}$, it was found that there were no significant differences between $E B$ and $Q E B$, but there was significantly lower bacterial growth than TCG+AB and TCG-AB group. At $72 \mathrm{~h}$, the trend was similar, with no significant differences between $\mathrm{EB}$ and $\mathrm{QEB}$ groups and showing a significantly lower bacterial growth than TCG+AB and TCG-AB groups. From $24 \mathrm{~h}$, bacterial growth in the TCG $+A B$ group increased over time, being three times higher at $72 \mathrm{~h}$ than that observed in groups EB and QEB, which maintained the same number of CFUs over time. 


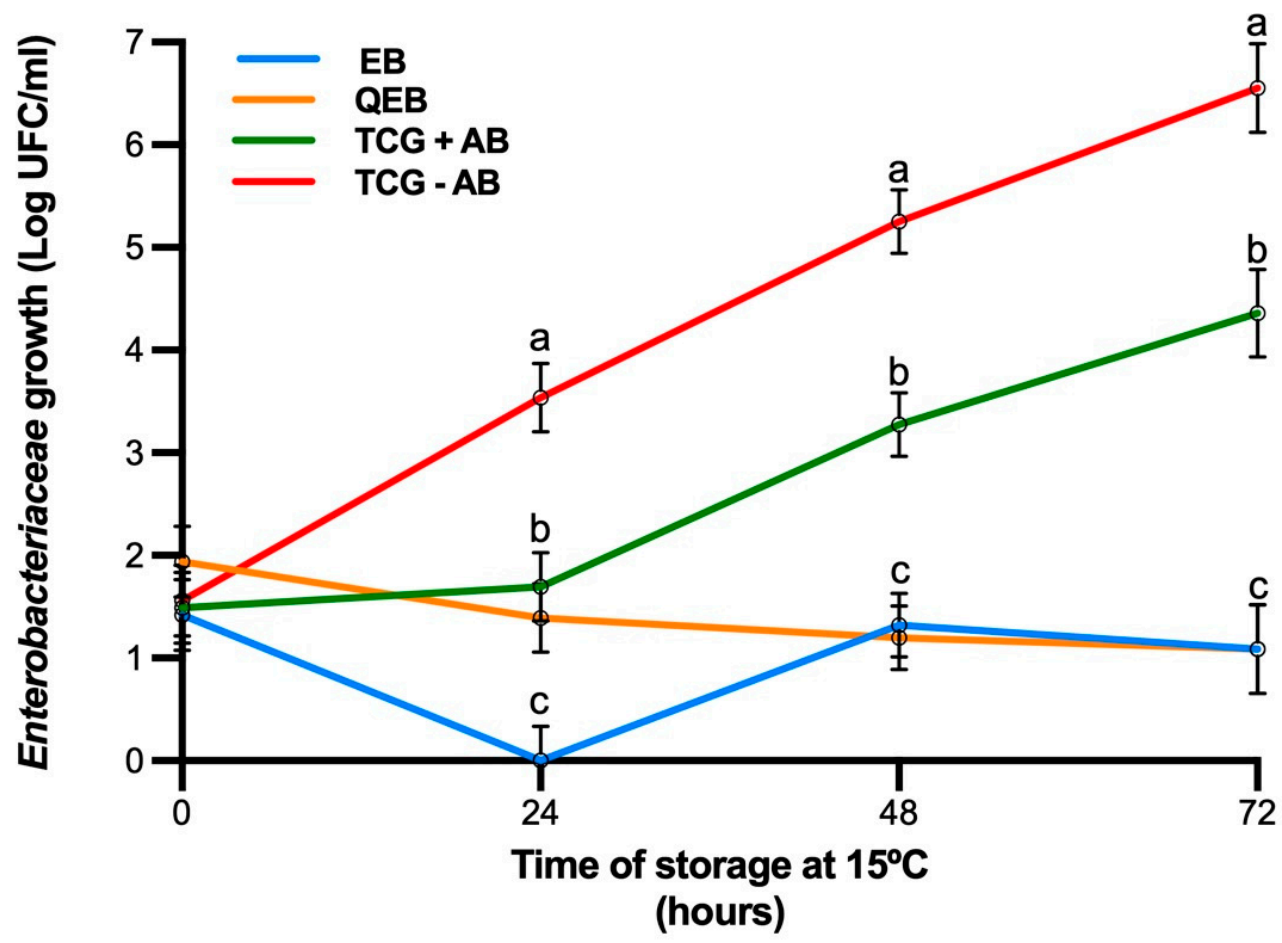

Figure 1. Bacterial growth (Log CFU/mL; mean $\pm \mathrm{SEM}$ ) in sperm samples from the rabbit where there was storage at $15^{\circ} \mathrm{C}$ for $72 \mathrm{~h}$ in four extenders: EB: TCG supplemented with EDTA (20 mM) and bestatin $(10 \mathrm{mM})$. QEB: TCG supplemented with EDTA $(20 \mathrm{mM})$, bestatin $(10 \mathrm{mM})$ and nanoparticles of chitosan-alginate $(0.05 \%)$. TCG + AB: TCG extender supplemented with $100 \mathrm{IU} / \mathrm{mL}$ penicillin $+100 \mu \mathrm{g} / \mathrm{mL}$ streptomycin. TCG-AB: TCG extender without antibiotics. Different superscripts $(a, b$ and $c)$ indicate differences in values at the same time point $(p<0.05)$.

Seminal quality parameters of samples from the experimental extenders are shown in Table 2. There was no interaction between extender and refrigeration time. The presence of EDTA, bestatin and chitosan nanoparticles had no effect on total motility, acrosome integrity, membrane functionality or the viability of spermatozoa. Following 24,48 and $72 \mathrm{~h}$, quality characteristics were retained in all groups, with no significant differences in motility, acrosome integrity, membrane functionality or the viability of spermatozoa.

Table 2. Sperm quality in stored rabbit spermatozoa in four extenders (means \pm standard deviation).

\begin{tabular}{cccccc}
\hline Extender Group & N & Total Mot (\%) & HOST (\%) & NAR (\%) & Viability (\%) \\
\hline TCG+AB & 9 & $73.9 \pm 9.98$ & $73.0 \pm 9.44$ & $94.2 \pm 6.18$ & $75.0 \pm 8.38$ \\
EB & 9 & $69.0 \pm 12.42$ & $73.4 \pm 8.41$ & $94.1 \pm 5.48$ & $72.0 \pm 7.00$ \\
QEB & 9 & $71.1 \pm 9.48$ & $72.6 \pm 6.38$ & $93.7 \pm 5.89$ & $72.7 \pm 7.43$ \\
TCG-AB & 9 & $68.8 \pm 11.19$ & $71.7 \pm 8.47$ & $94.6 \pm 5.79$ & $73.2 \pm 6.09$ \\
\hline Time & & & & \\
\hline $24 \mathrm{~h}$ & 12 & $73.8 \pm 11.95$ & $75.1 \pm 7.41$ & $96.1 \pm 4.96$ & $74.8 \pm 6.82$ \\
$48 \mathrm{~h}$ & 12 & $72.0 \pm 12.58$ & $71.6 \pm 8.78$ & $94.5 \pm 6.78$ & $72.6 \pm 8.61$ \\
$72 \mathrm{~h}$ & 12 & $66.3 \pm 4.43$ & $71.3 \pm 7.59$ & $91.8 \pm 5.01$ & $72.3 \pm 5.76$
\end{tabular}

UTCG+AB: TCG extender supplemented with $100 \mathrm{IU} / \mathrm{mL}$ penicillin $+100 \mu \mathrm{g} / \mathrm{mL}$ streptomycin. EB: TCG supplemented with EDTA $(20 \mathrm{mM})$ and bestatin $(10 \mathrm{mM})$. QEB: TCG supplemented with EDTA $(20 \mathrm{mM})$, bestatin $(10 \mathrm{mM})$ and nanoparticles of chitosan-alginate $(0.05 \%)$. TCG-AB: TCG extender without antibiotics. N: number of seminal pools; Total Mot: total motility; HOST: hypo-osmotic swelling test; NAR: acrosome normality.

\subsection{Experiment 2: In Vivo Evaluation}

Pregnancy rate at birth and the total number of kits born are presented in Table 3. Neither pregnancy rate at birth nor prolificacy were affected by the experimental group, both parameters being similar between groups. 
Table 3. Fertility (\%) and prolificacy (means \pm standard deviation) obtained from insemination of 897 females.

\begin{tabular}{cccc}
\hline Extender Group & N & Pregnancy Rate (\%) & Total Number of Kits Born \\
\hline TCG + AB & 228 & 90 & $10.1 \pm 3.20$ \\
EB & 225 & 88 & $10.0 \pm 3.50$ \\
QEB & 219 & 88 & $10.3 \pm 3.17$ \\
TCG-AB & 225 & 87 & $10.2 \pm 3.25$
\end{tabular}

TCG+AB: TCG extender supplemented with $100 \mathrm{IU} / \mathrm{mL}$ penicillin $+100 \mu \mathrm{g} / \mathrm{mL}$ streptomycin. EB: TCG supplemented with EDTA $(20 \mathrm{mM})$ and bestatin $(10 \mathrm{mM})$. QEB: TCG supplemented with EDTA $(20 \mathrm{mM})$, bestatin $(10 \mathrm{mM})$ and nanoparticles of chitosan-alginate $(0.05 \%)$. TCG-AB: TCG extender without antibiotics. N: number of inseminated does.

\section{Discussion}

Bacterial contamination is of particular relevance in rabbit AI, where most inseminations are carried out with liquid semen storage at $15{ }^{\circ} \mathrm{C}$ [43]. Even though semen collection protocols in the livestock industry are very strict, semen collection is not a sterile process, and the addition of antibiotics to extenders to control contaminating bacterial populations is a routine fact at farm level. The efficacy of different antibiotics added to semen extenders in livestock has been widely demonstrated [44]. However, how quickly bacteria acquire tolerance and/or resistance to antibiotics is essential. Numerous studies show the critical resistance patterns found in semen samples of different species such as boars [45], humans [46] and bovine [47]. However, it can be suggested that the antibiotics currently used in routine practices in livestock, such as AI, may need to be modified to avoid future complications arising from bacterial resistance.

Previous study demonstrated that sperm microbiota diversity is influenced by host genetics [9]. The rabbit semen samples were contaminated with bacteria, especially those that belong to the Enterobacteriaceae family [44], ranging from $27.6 \%$ for Line V to $50.9 \%$ for Line R of semen samples analysed [9]. Bacteria contamination, such as Enterobacteriaceae family might adversely affect the quality of semen used for AI [4] and is an important hygiene indicator [5], although the majority of these bacterial strains are not currently considered pathogens [7]. The results of this study prove that the replacement of antibiotics in the current extenders by EDTA and bestatin prevent bacterial growth through $72 \mathrm{~h}$ in the rabbit doses. Therefore, the present study results validate the bacteriostatic effect of aminopeptidase inhibitors, such as bestatin and EDTA, and highlight the role of protease inhibitors in the control of seminal bacterial growth. This is in agreement with several studies in which an inhibitory activity of EDTA against Gram-negative bacteria, Grampositive bacteria (staphylococci) and fungi (Candida spp.) was observed [33-35]. Likewise, some studies indicated that EDTA, alone or in combination, is an effective antibiofilm agent with a spectrum covering both Gram-positive and Gram-negative bacteria [35,48-52] In addition, bacterial proteases participate in important metabolic pathways and have key roles in cell viability, stress response and pathogenicity [53]. On the other hand, despite the antimicrobial activity demonstrated by chitosan against several pathogens [54-56], in the present study, the presence of chitosan-alginate nanoparticles in the extender did not show a synergistic action with aminopeptidase inhibitors on the microbial growth, with both extenders showing similar results. A possible explanation for this is that the presence of alginate can interfere in the inhibition of bacterial growth by chitosan. As the presence of cationic charge situated in the amino group of chitosan is essential for exhibiting high antimicrobial properties [57], the ionic linkages between functional groups of the oppositely charged chitosan and alginate would result in low availability of unreacted positive amino groups of chitosan when nanoparticles were formed, which reduces the chances of interaction with negatively charged components of microbial cell membranes. Our results suggest that both aminopeptidase inhibitors (EDTA and bestatin), alone or in combination with nanoparticles of chitosan-alginate, maintained total motility, viability, acrosome status and functional integrity of the sperm plasma membrane for at least three days. Moreover, the use of both aminopeptidase inhibitors preserved the fertility and prolificacy under field 
conditions. Undoubtedly, this result could be used to improve the sustainability of the rabbit production system. In the present study, the classic combination of penicillin and streptomycin contributed to the diluent's efficacy in controlling the growth of Enterobacteriaceae only for up to $24 \mathrm{~h}$. Nevertheless, from this moment on, this antibiotic cocktail cannot prevent the bacterial growth, which was probably due to an increase in tolerance of antibiotics by Enterobacteriaceae $[58,59]$. The common use of antibiotics in extenders is an important concern: apart from being prophylactic and non-therapeutic, and therefore going against the recommendations for prudent use of antimicrobials, they can cause increase antibiotic resistance in the bacteria commonly found in semen [24]. As expected, in the extender without antibiotics (TCG-AB), no bacteriostatic effect was observed throughout the entire cooling period, showing an increasing number of enterobacteria over time, highlighting the need to supplement AI extenders with substances that control bacterial growth. However, there were no effects of enterobacteria contamination on in vitro quality sperm in long-term stored samples. Although the presence of microorganisms in semen may reduce semen quality and fertilising capacity during preservation time, our results indicate that bacterial concentration present in fresh semen ( 0 to $4 \mathrm{~h}$ from semen collection) has no effect on reproductive performance, which is in agreement with Jäkel et al. [60] in pig, who reported similar reproductive performance at $24 \mathrm{~h}$ between groups inseminated with semen diluted in extender with or without antibiotics. Extenders and storage temperature are important factors to preserve the fertilising capacity of rabbit semen. As regards the sperm quality variables, all extenders used in the present study preserved the quality of rabbit semen throughout the cooling period. Several studies to evaluate stored rabbit semen have been carried out under different experimental conditions. On the one hand, several authors had observed that motility decreased when semen was stored at $5^{\circ} \mathrm{C}$ during $48 \mathrm{~h}$, irrespective of the extender used [61-63]. On the other hand, other authors have shown that rabbit semen stored at $15{ }^{\circ} \mathrm{C}$ up to $48 \mathrm{~h}$ retains fertility capacity [43,64]. However, further studies are needed to verify the reproductive performance of rabbit semen stored for $72 \mathrm{~h}$ in extenders supplemented with EDTA and bestatin.

\section{Conclusions}

In conclusion, we demonstrated in this study that the addition of EDTA and bestatin to semen extender exerted a potent bacteriostatic effect over time, effectively inhibiting the growth of Enterobacteriaceae, which suggests that EDTA and bestatin could be used as an alternative to conventional antibiotics in rabbit semen extenders.

Author Contributions: Conceptualisation M.P.V.-d.-C., C.M.; Methodology and data curation M.P.V.-d.-C., C.M., F.M.-J. and J.S.V.; writing-original draft preparation, M.P.V.-d.-C.; writing and analysisreview and editing, M.P.V.-d.-C., C.M., F.M.-J. and J.S.V. All authors have read and agreed to the published version of the manuscript.

Funding: Funding from the Ministry of Economy, Industry and Competitiveness (Research project: AGL2017-85162-C2-1-R) is acknowledged.

Institutional Review Board Statement: The study was conducted according to the guidelines of the Declaration of Helsinki, and approved by the Animal Care and Use Committee of Centro de Tecnología Animal, Instituto Valenciano de Investigaciones Agrarias (Protocol \#2018/VSC/PEA/0116).

Acknowledgments: The authors thank Manuel Sierra and Felipe Lavara for offering their animal facility for conducting this study under field conditions.

Conflicts of Interest: The authors declare no conflict of interest. 


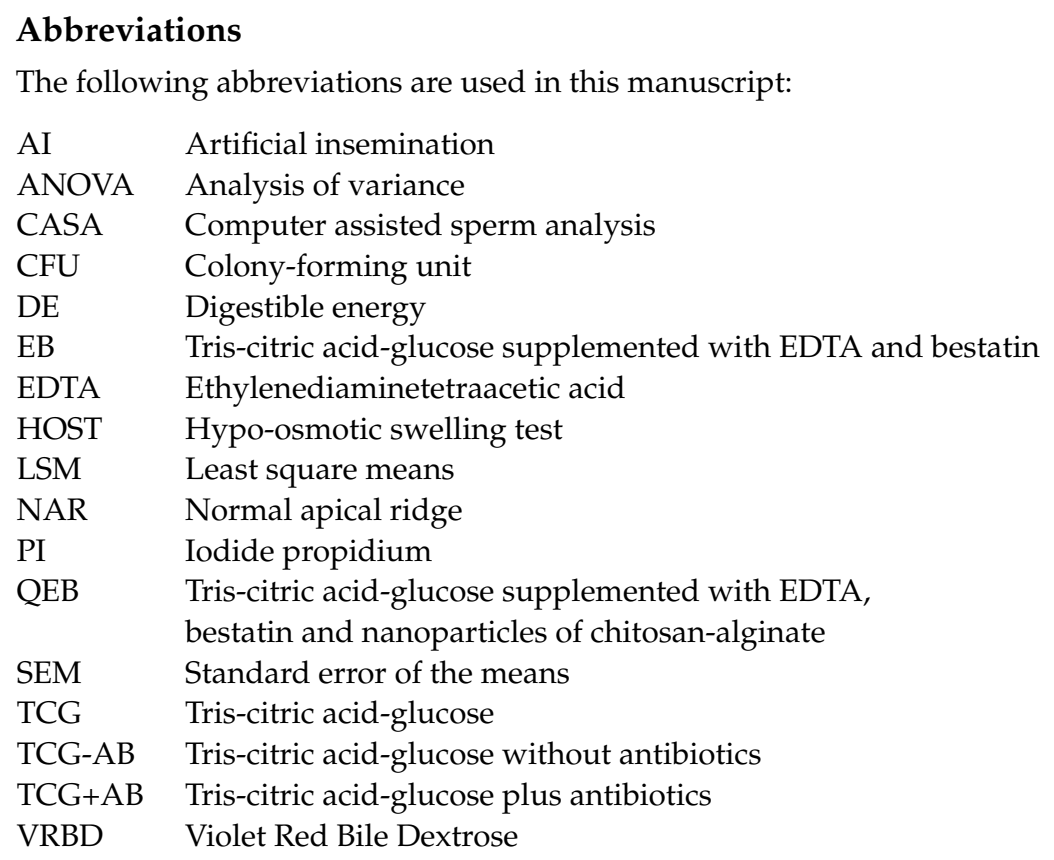

\section{References}

1. Waberski, D.; Riesenbeck, A.; Schulze, M.; Weitze, K.F.; Johnson, L. Application of preserved boar semen for artificial insemination: Past, present and future challenges. Theriogenology 2019, 137, 2-7. [CrossRef]

2. Da Costa, P.M.; Loureiro, L.; Matos, A.J.F. Transfer of multidrug-resistant bacteria between intermingled ecological niches: The interface between humans, animals and the environment. Int. J. Environ. Res. Public Health 2013, 10, 278-294. [CrossRef]

3. Agrawal, Y.; Vanha-Perttula, T. Alanyl aminopeptidase of bovine seminal vesicle secretion. Int. J. Biochem. 1986, 18, 725-729. [CrossRef]

4. Althouse, G.C.; Lu, K.G. Bacteriospermia in extended porcine semen. Theriogenology 2005, 63, 573-584. [CrossRef] [PubMed]

5. Halkman, H.B.D.; Halkman, A.K. Indicator Organisms. In Encyclopedia of Food Microbiology, 2nd ed.; Elsevier Inc.: Amsterdam, The Netherlands, 2014; pp. 358-363. ISBN 9780123847331.

6. Asociación Española de Normalización y Certificación. Microbiology of the Food Chain. Horizontal Method for the Detection and Enumeration of Enterobacteriaceae. Part 2: Colony-Count Technique (ISO 21528-2:2017, Corrected Version 2018-06-01). 2018. Available online: https://www.en.une.org/_layouts/15/r.aspx?c=N0059874 (accessed on 20 March 2021).

7. European Food Safety Authority; European Centre for Disease Prevention and Control. The European Union Summary Report on Antimicrobial Resistance in Zoonotic and Indicator Bacteria from Humans, Animals and Food in 2017/2018. EFSA J. 2020, 18, e06007. [CrossRef]

8. Moretti, E.; Capitani, S.; Figura, N.; Pammolli, A.; Federico, M.G.; Giannerini, V.; Collodel, G. The presence of bacteria species in semen and sperm quality. J. Assist. Reprod. Genet. 2009, 26, 47-56. [CrossRef] [PubMed]

9. Úbeda, J.L.; Ausejo, R.; Dahmani, Y.; Falceto, M.V.; Usan, A.; Malo, C.; Perez-Martinez, F.C. Adverse effects of members of the Enterobacteriaceae family on boar sperm quality. Theriogenology 2013, 80, 565-570. [CrossRef] [PubMed]

10. Marco-Jiménez, F.; Borrás, S.; Garcia-Dominguez, X.; D'Auria, G.; Vicente, J.S.; Marin, C. Roles of host genetics and sperm microbiota in reproductive success in healthy rabbit. Theriogenology 2020, 158, 416-423. [CrossRef] [PubMed]

11. Althouse, G. Sanitary Procedures for the Production of Extended Semen. Reprod. Domest. Anim. 2008, 43, 374-378. [CrossRef] [PubMed]

12. Huang, K.; Takahara, S.; Kinouchi, T.; Takeyama, M.; Ishida, T.; Ueyama, H.; Nishi, K.; Ohkubo, I. Alanyl Aminopeptidase from Human Seminal Plasma: Purification, Characterization, and Immunohistochemical Localization in the Male Genital Tract. J. Biochem. 1997, 122, 779-787. [CrossRef] [PubMed]

13. Fernández, D.; Valdivia, A.; Irazusta, J.; Ochoa, C.; Casis, L. Peptidase activities in human semen. Peptides 2002, 23, 461-468. [CrossRef]

14. Irazusta, J.; Valdivia, A.; Fernández, D.; Agirregoitia, E.; Ochoa, C.; Casis, L. Enkephalin-degrading enzymes in normal and subfertile human semen. J. Androl. 2004, 25, 733-739. [CrossRef]

15. Osada, T.; Watanabe, G.; Kondo, S.; Toyoda, M.; Sakaki, Y.; Takeuchi, T. Male reproductive defects caused by puromycin-sensitive aminopeptidase deficiency in mice. Mol. Endocrinol. 2001, 15, 960-971. [CrossRef] [PubMed]

16. Viudes-de-Castro, M.P.; Mocé, E.; Lavara, R.; Marco-Jiménez, F.; Vicente, J.S. Aminopeptidase activity in seminal plasma and effect of dilution rate on rabbit reproductive performance after insemination with an extender supplemented with buserelin acetate. Theriogenology 2014, 81, 1223-1228. [CrossRef] [PubMed] 
17. Bhosale, M.; Kadthur, J.C.; Nandi, D. Roles of Salmonella enterica serovar Typhimurium encoded Peptidase N during systemic infection of Ifn $\gamma$-/- mice. Immunobiology 2012, 217, 354-362. [CrossRef]

18. Correa, A.F.; Bastos, I.M.D.; Neves, D.; Kipnis, A.; Junqueira-Kipnis, A.P.; de Santana, J.M. The activity of a hexameric M17 metallo-aminopeptidase is associated with survival of Mycobacterium tuberculosis. Front. Microbiol. 2017, 8, 504. [CrossRef] [PubMed]

19. Agyare, C.; Etsiapa Boamah, V.; Ngofi Zumbi, C.; Boateng Osei, F. Antibiotic Use in Poultry Production and Its Effects on Bacterial Resistance. In Antimicrobial Resistance-A Global Threat; IntechOpen: London, UK, 2019.

20. Sharma, V.K.; Johnson, N.; Cizmas, L.; McDonald, T.J.; Kim, H. A review of the influence of treatment strategies on antibiotic resistant bacteria and antibiotic resistance genes. Chemosphere 2016, 150, 702-714. [CrossRef]

21. Nicholson, C.M.; Abramsson, L.; Holm, S.E.; Bjurulf, E. Bacterial contamination and sperm recovery after semen preparation by density gradient centrifugation using silane-coated silica particles at different $\mathrm{g}$ forces. Hum. Reprod. 2000, 15, 662-666. [CrossRef]

22. Morrell, J.M.; Klein, C.; Lundeheim, N.; Erol, E.; Troedsson, M.H.T. Removal of bacteria from stallion semen by colloid centrifugation. Anim. Reprod. Sci. 2014, 145, 47-53. [CrossRef]

23. Guimarães, T.; Lopes, G.; Pinto, M.; Silva, E.; Miranda, C.; Correia, M.J.; Damásio, L.; Thompson, G.; Rocha, A. Colloid centrifugation of fresh stallion semen before cryopreservation decreased microorganism load of frozen-thawed semen without affecting seminal kinetics. Theriogenology 2015, 83, 186-191. [CrossRef]

24. Martínez-Pastor, F.; Lacalle, E.; Martínez-Martínez, S.; Fernández-Alegre, E.; Álvarez-Fernández, L.; Martinez-Alborcia, M.-J.; Bolarin, A.; Morrell, J.M. Low density Porcicoll separates spermatozoa from bacteria and retains sperm quality. Theriogenology 2021, 165. [CrossRef]

25. Ramires Neto, C.; Sancler da Silva, Y.F.R.; Resende, H.L.; Guasti, P.N.; Monteiro, G.A.; Papa, P.M.; Dell'aqua Júnior, J.A.; Puoli Filho, J.N.P.; Alvarenga, M.A.; Papa, F.O. Control methods and evaluation of bacterial growth on fresh and cooled stallion semen. J. Equine Vet. Sci. 2015, 35, 277-282. [CrossRef]

26. Finnegan, S.; Percival, S.L. EDTA: An Antimicrobial and Antibiofilm Agent for Use in Wound Care. Adv. Wound Care 2015, 4, 415-421. [CrossRef]

27. Rabea, E.I.; Badawy, M.E.T.; Stevens, C.V.; Smagghe, G.; Steurbaut, W. Chitosan as antimicrobial agent: Applications and mode of action. Biomacromolecules 2003, 4, 1457-1465. [CrossRef]

28. Sahariah, P.; Másson, M. Antimicrobial Chitosan and Chitosan Derivatives: A Review of the Structure-Activity Relationship. Biomacromolecules 2017, 18, 3846-3868. [CrossRef] [PubMed]

29. Rudramurthy, G.R.; Swamy, M.K.; Sinniah, U.R.; Ghasemzadeh, A. Nanoparticles: Alternatives against drug-resistant pathogenic microbes. Molecules 2016, 21, 836. [CrossRef] [PubMed]

30. Bahar, A.; Ren, D. Antimicrobial Peptides. Pharmaceuticals 2013, 6, 1543-1575. [CrossRef] [PubMed]

31. Mahlapuu, M.; Håkansson, J.; Ringstad, L.; Björn, C. Antimicrobial peptides: An emerging category of therapeutic agents. Front. Cell. Infect. Microbiol. 2016, 6, 194. [CrossRef]

32. Dickneite, G.; Schorlemmer, H.U.; Hofstaetter, T.; Sedlacek, H.-H. Immunostimulation as a Therapeutic Principle in Bacterial Infections: The Effect of the Immunomodulator Bestatin on the Experimental Chronic E. coli Urinary Tract Infection. In Experimentelle Urologie; Springer: Berlin/Heidelberg, Germany, 1985; pp. 229-235.

33. Root, J.L.; McIntyre, O.R.; Jacobs, N.J.; Daghlian, C.P. Inhibitory effect of disodium EDTA upon the growth of Staphylococcus epidermidis in vitro: Relation to infection prophylaxis of Hickman catheters. Antimicrob. Agents Chemother. 1988, 32, 1627-1631. [CrossRef] [PubMed]

34. Gil, M.L.; Casanova, M.; Martínez, J.P. Changes in the cell wall glycoprotein composition of Candida albicans associated to the inhibition of germ tube formation by EDTA. Arch. Microbiol. 1994, 161, 489-494. [CrossRef] [PubMed]

35. Percival, S.L.; Kite, P.; Eastwood, K.; Murga, R.; Carr, J.; Arduino, M.J.; Donlan, R.M. Tetrasodium EDTA as a Novel Central Venous Catheter Lock Solution Against Biofilm. Infect. Control Hosp. Epidemiol. 2005, 26, 515-519. [CrossRef]

36. Li, J.; Cai, C.; Li, J.; Li, J.; Li, J.; Sun, T.; Wang, L.; Wu, H.; Yu, G. Chitosan-Based Nanomaterials for Drug Delivery. Molecules 2018, 23, 2661. [CrossRef] [PubMed]

37. Liu, X.F.; Guan, Y.L.; Yang, D.Z.; Li, Z.; Yao, K. Antibacterial action of chitosan and carboxymethylated chitosan. J. Appl. Polym. Sci. 2001, 79, 1324-1335. [CrossRef]

38. Hosseinnejad, M.; Jafari, S.M. Evaluation of different factors affecting antimicrobial properties of chitosan. Int. J. Biol. Macromol. 2016, 85, 467-475. [CrossRef]

39. Casares-Crespo, L.; Vicente, J.S.; Talaván, A.M.; Viudes-de-Castro, M.P. Does the inclusion of protease inhibitors in the insemination extender affect rabbit reproductive performance? Theriogenology 2016, 85, 928-932. [CrossRef] [PubMed]

40. Casares-Crespo, L.; Fernández-Serrano, P.; Viudes-de-Castro, M.P. Protection of GnRH analogue by chitosan-dextran sulfate nanoparticles for intravaginal application in rabbit artificial insemination. Theriogenology 2018, 116, 49-52. [CrossRef]

41. Viudes-De-Castro, M.P.; Vicente, J.S. Effect of sperm count on the fertility and prolificity rates of meat rabbits. Anim. Reprod. Sci. 1997, 46, 313-319. [CrossRef]

42. Estany, J.; Camacho, J.; Baselga, M.; Blasco, A. Selection response of growth rate in rabbits for meat production. Genet. Sel. Evol. 1992, 24, 527-537. [CrossRef]

43. Roca, J.; Martínez, S.; Vázquez, J.M.; Lucas, X.; Parrilla, I.; Martínez, E.A. Viability and fertility of rabbit spermatozoa diluted in Tris-buffer extenders and stored at $15^{\circ} \mathrm{C}$. Anim. Reprod. Sci. 2000, 64, 103-112. [CrossRef] 
44. Duracka, M.; Lukac, N.; Kacaniova, M.; Kantor, A.; Hleba, L.; Ondruska, L.; Tvrda, E. Antibiotics versus natural biomolecules: The case of in vitro induced bacteriospermia by enterococcus faecalis in rabbit semen. Molecules 2019, 24, 4329. [CrossRef] [PubMed]

45. Bennemann, P.E.; Machado, S.A.; Girardini, L.K.; Sonálio, K.; Tonin, A.A. Bacterial contaminants and antimicrobial susceptibility profile of boar semen in Southern Brazil Studs. Rev. MVZ Córdoba 2018, 23, 6637-6648. [CrossRef]

46. Machen, G.L.; Bird, E.T.; Brown, M.L.; Ingalsbe, D.A.; East, M.M.; Reyes, M.; Kuehl, T.J. Time trends for bacterial species and resistance patterns in semen in patients undergoing evaluation for male infertility. Baylor Univ. Med. Cent. Proc. 2018, 31, 165-167. [CrossRef] [PubMed]

47. Jayarao, B.M.; Oliver, S.P. Aminoglycoside-Resistant Streptococcus and Enterococcus Species Isolated from Bovine Mammary Secretions. J. Dairy Sci. 1992, 75, 991-997. [CrossRef]

48. Raad, I.; Hanna, H.; Dvorak, T.; Chaiban, G.; Hachem, R. Optimal antimicrobial catheter lock solution, using different combinations of minocycline, EDTA, and 25-percent ethanol, rapidly eradicates organisms embedded in biofilm. Antimicrob. Agents Chemother. 2007, 51, 78-83. [CrossRef] [PubMed]

49. Kite, P.; Eastwood, K.; Sugden, S.; Percival, S.L. Use of in vivo-generated biofilms from hemodialysis catheters to test the efficacy of a novel antimicrobial catheter lock for biofilm eradication in vitro. J. Clin. Microbiol. 2004, 42, 3073-3076. [CrossRef] [PubMed]

50. Banin, E.; Brady, K.M.; Greenberg, E.P. Chelator-induced dispersal and killing of Pseudomonas aeruginosa cells in a biofilm. Appl. Environ. Microbiol. 2006, 72, 2064-2069. [CrossRef]

51. Sherertz, R.J.; Boger, M.S.; Collins, C.A.; Mason, L.; Raad, I.I. Comparative in vitro efficacies of various catheter lock solutions. Antimicrob. Agents Chemother. 2006, 50, 1865-1868. [CrossRef]

52. Al-Bakri, A.G.; Othman, G.; Bustanji, Y. The assessment of the antibacterial and antifungal activities of aspirin, EDTA and aspirin-EDTA combination and their effectiveness as antibiofilm agents. J. Appl. Microbiol. 2009, 107, 280-286. [CrossRef]

53. Culp, E.; Wright, G.D. Bacterial proteases, untapped antimicrobial drug targets. J. Antibiot. 2017, 70, 366-377. [CrossRef]

54. Goy, R.C.; Morais, S.T.B.; Assis, O.B.G. Evaluation of the antimicrobial activity of chitosan and its quaternized derivative on E. Coli and S. aureus growth. Rev. Bras. Farmacogn. 2016, 26, 122-127. [CrossRef]

55. Erdem, B.; Kariptaş, E.; Kaya, T.; Tulumoğlu, Ş.; Görgülü, Ö. Factors influencing antibacterial activity of chitosan against Aeromonas hydrophila and Staphylococcus aureus. Int. Curr. Pharm. J. 2016, 5, 45-48. [CrossRef]

56. Li, J.; Zhuang, S. Antibacterial activity of chitosan and its derivatives and their interaction mechanism with bacteria: Current state and perspectives. Eur. Polym. J. 2020, 138, 109984. [CrossRef]

57. Holappa, J.; Hjálmarsdóttir, M.; Másson, M.; Rúnarsson, Ö.; Asplund, T.; Soininen, P.; Nevalainen, T.; Järvinen, T. Antimicrobial activity of chitosan N-betainates. Carbohydr. Polym. 2006, 65, 114-118. [CrossRef]

58. Levin-Reisman, I.; Brauner, A.; Ronin, I.; Balaban, N.Q. Epistasis between antibiotic tolerance, persistence, and resistance mutations. Proc. Natl. Acad. Sci. USA 2019, 116, 14734-14739. [CrossRef] [PubMed]

59. Windels, E.M.; Michiels, J.E.; van den Bergh, B.; Fauvart, M.; Michiels, J. Antibiotics: Combatting tolerance to stop resistance. MBio 2019, 10, e02095-19. [CrossRef] [PubMed]

60. Jäkel, H.; Scheinpflug, K.; Mühldorfer, K.; Gianluppi, R.; Lucca, M.S.; Mellagi, A.P.G.; Bortolozzo, F.P.; Waberski, D. In vitro performance and in vivo fertility of antibiotic-free preserved boar semen stored at $5{ }^{\circ} \mathrm{C}$. J. Anim. Sci. Biotechnol. 2021, 12, 1-12. [CrossRef]

61. El-Gaafary, M.N. Quality and fertility of cooled rabbit semen supplemented with cyclic-AMP stimulators. Anim. Reprod. Sci. 1994, 34, 307-313. [CrossRef]

62. El-Kelawy, H.M.; Tawfeek, M.I.; El-Gaafary, M.N.; Ibrahim, H. Viability and Fertilizing Ability of Extended Rabbit Semen Stored at $5^{\circ} \mathrm{C}$. In Proceedings of the 10th World Rabbit Congress, Sharm EL-Sheikh, Egypt, 3-6 September 2012; pp. $285-289$.

63. Rosato, M.P.; Iaffaldano, N. Effect of Chilling Temperature on the Long-Term Survival of Rabbit Spermatozoa held Either in a Tris-Based or a Jellified Extender. Reprod. Domest. Anim. 2011, 46, 301-308. [CrossRef]

64. López-Gatius, F.; Sances, G.; Sancho, M.; Yániz, J.; Santolaria, P.; Gutiérrez, R.; Núñez, M.; Núñez, J.; Soler, C. Effect of solid storage at $15{ }^{\circ} \mathrm{C}$ on the subsequent motility and fertility of rabbit semen. Theriogenology 2005, 64, 252-260. [CrossRef] 